\title{
Albanian "Bologna" \\ How close/far is Albanian Higher Education to European standards?
}

\author{
Dr. Tomi Treska \\ European University of Tirana \\ Dr. Erjona Canaj \\ European University of Tirana
}

\section{Doi:10.5901/mjss.2013.v4n10p666}

\begin{abstract}
Bologna process brought many important changes in the Albanian higher education system. The main objective of the Bologna system of higher education is to achieve European standards in access as well as the quality of the studies. Higher education system in Albania appears to be reformed on the basis of published and already accepted standards in member countries of the European Higher Education Area, making it comparable and compatible with other European systems of higher education. Significant results so far speak for its positive influence and it has open new perspectives towards a European quality education of the Albanian students. However, there are still challenges and difficulties. The purpose of this paper is to present a comprehensive analysis of the European higher education legislation; the study of some essential elements of this system as the financing system of universities, ECTS, and recognition/non-recognition of Albanian degrees in European countries, in order to define how close/far is Albanian Higher Education System to the European standards.
\end{abstract}

Keywords: European legislation, higher education, ECTS, mobility, diploma recognition etc.

\section{Introduction}

In 2012, the higher education panorama results to be transformed due to Bologna System/Process. All the Member States of this process have realized significant changes that have facilitated the European High Education Area (Ehea/Heal) to be better determined by laying down the foundations for a higher education which will fulfill the ongoing increasing requests of the society. The higher education structures have changed: developing in principle stable systems of quality and the mechanisms to facilitate the mobility of both students and the docents. Furthermore, the current issues are already defined and projected in a social dimension of Higher Education. Such a project, unprecedented in itself, based on volunteer cooperation, separation and implementation of common objectives of the Higher Education systems of the 47 member states. Albania is one of those states that have signed and implemented Bologna Agreement. Nowadays, Albania is a member of NATO and aspires to receive the Status of candidate country to the European Union. Certainly, this huge step, on the one hand requires the consolidation of democracy, a considerable economic development, constant battling against poverty, and on the other hand, it obligates the approximation of the legislation framework in the field of education in comply with the international and European standards.

In years, in the conferences and the meetings of the ministers, it is underlined the fact that Europe should face with the global dynamic economy, based on knowledge, capable to deal with the economic increase by means of more modern and complementary actions, as well as a stronger social cohesion. The goal of these structures is preservation of the cultural richness and language diversity, based on the diversity of the assets and the inherited traditions from different cultural groups. Particularly, in the Ministers Conference of the Education in Berlin (2003), where the ministers accepted the Albanian request to be included in Bologna Process, they declared that membership means a fundamental reform for all the signing countries, approximation of the legislation and creation of a common space, open and flexible for the Higher Education.

Nowadays, it is already a fact, that Bologna Process has brought very important changes in the Albanian Higher Education. The main goal for the Albanian Higher Education is achieving European standards in access and studying quality, too. The Albanian higher education System seems to be reformed based on the standards determined and already accepted in all the member countries of the European Higher Education Zone (EHEA) making it comparable 
and in compliance with the other European Higher Education Systems. This reformation has involved all the links of the system and one of the greatest achievements of this reformation is its massive character, like in the whole world, as the Higher Education does not any more belong to the elite. 2002 marked the beginning of Private Higher Education in our country. Since then, the number of higher education institutions and the number of the study programs is obviously increased, and the rapid increase of the number of students from 2005 up to now has accomplished its objective to become massive. Being in front of this fast growth, this process has also brought forth a number of problems that converge in a single point that is the quality. The current results demonstrate its positive impact and also create new perspectives for all the Albanian students towards the European qualitative education. Nevertheless, its problems in our country are numerous.

\section{The whole European legal framework and in particular Bologna System's covered by its historical raiment}

An increasing world toward the economic interdependence, culture and communication still needs "pole positions" and transparent, discussions and clearly defined policies that are at the same level with the new social situation and above all capable of designing creative and functional mechanisms. In the recent decades, at the level of the international institutions, it is gradually raised the awareness that the deep economic and socio-cultural changes consolidate the future of the society. This perspective has particularly become evident in the 10-years reports of UNESCO, in the resolutions of the European Council in the field of education and culture as well as in documents related to the various stages that have marked the development of the European Union. Especially, at the level of the European Union, it is confirmed the conviction that the future of the continent can not be based only on economic aspects, but it is necessary to deal with the deep cultural, social and technological evolution, innovation taking place nowadays worldwide (Scurati - Bocca 1999). To cope with these changes, it is essential that the education process provided for the future generations should be reviewed deeply.

In fact, the education and the professional formation discipline has never been on of the fields where, according to the treaties, the European Community has had reliable legislative competence. As it is well-known, the Community's competences were extended in four primary fields like: free flow of goods, free movements of people, services, and capitals; thus education was not part of these policies. Traditionally, the university has evaluated in Europe inside the borderlines of each State - Nation, although the consequences were mainly connected to: differentiation, in a specific way, has been the main barrier to the transparency, clarity and mobility: cooperation that was reduced to personal relationships and a limited number of bilateral agreements. Beginning from mid '80-s, the European Union has started some successful programs aiming at strengthening the international cooperation and above it was made possible the mobility of more than 100.000 students a year.

The first initiative in this field goes back to 1984, the year when it was drafted the instrument to support the research and the development at community level called "multi-annual framework program for research and technological development ESPRIT" which has fixed periodical scientific and technological objectives through which it aims at the increase of the international competition as well as it has shown the general lines of action to achieve these objectives.

Immediately, after four years on 18 September 1988, the European University Rectors, gathered in Bologna, at the $900^{\text {th }}$ anniversary of the foundation of the first university of that city, signed Magna Charta Universitatum ${ }^{1}$. In that document, it is sanctioned some principles that are later incorporated in the Declaration of 1999. It is sanctioned, for example, that humanity future greatly depends on the cultural, scientific and technical development that takes place in the centers of culture, knowledge and research; it is reaffirmed the principle by which the universities, cults of tradition, European humanism, but with the commitment to reach universal knowledge, developing their functions, they overcome the geographical or political borders and affirm the necessary need for mutual understanding and interaction of cultures; among the manners to achieve these objectives, it shows the professors and students mobility and believes that a general unified and constant policy regarding the status, academic titles and exams (meanwhile it is guaranteed the recognition of the international diplomas), and represents an important instrument to assure practicing of the actual mission of the Universities.

The European Community hereafter determined the education and the professional formation as one of its main goals. There are precisely the articles (ex-articles) 149 and 150 of the foundation Treaty of the European Community that provided the EU the general competence to draft norms and stimulating actions in the field of education and the

${ }^{1}$ See the full text of Magna Charta in www.unibo.it/avl/charta/charta.htm 
professional qualification. These dispositions in explicit way excluded "the harmonization of whatever legislative disposition or regulations of the member states", leaving it to the member states themselves.

The Article 149 TKE (actually incorporated in the article 165 TFBE) offered the contribution of the European Community in the development of the qualitative education with the support and the fulfilling of the policies of the member states in connection with the teachings contents and organization of the education system, respecting their language and cultural diversity. While the article 150 (actually incorporated in the article 165 TFBE) of the EC treaty contemplated the creation of a policy on the professional formation that reinforces and fulfills the member states policies, respecting completely the responsibility of the latest regarding the substance and organization of the professional training.

Another important moment before Bologna Declaration is "Lisbon Convention" approved on 11 April $1997^{2}$. In this document, it are specified the fundamental principles and the comparable credits in the studying programs in relation to the time and the activities, the academic titles and the recognition procedures of diplomas, as well as of the qualification certificates of Higher Education in the European area, to facilitate the academic mobility among the different countries. The convention, respecting the autonomy of the different countries institutions, aims to establish a common system of diplomas and academic titles bestowed at its end easily readable and comparable. Based on these principles, the Convention is traversed by the goal to facilitate it, thus, for the citizens of every Union Country, the access in each country's education system.

Another important moment in the architecture of the system mentioned above, constitutes Sorbonne Declaration, signed on 25 May 1998, made by the initiative of the Education Ministers of France, Germany, United Kingdom and Italy, aiming at harmonizing of the European high education architecture. In this declaration, it was stressed the importance of the transformation of the higher education system aiming giving it a new cultural dimension to all the European universities in the European Zone and the need of a positive convergence of all the diplomas and their cycles inside the EU. In the meantime, in EU, it is also confirmed, in factual manner, a real current labor market inside EU, which requires from the education and training system, especially from the higher education, adequate process to the young and the adults (Malizia 2005). In this context, almost everyone agree that "strategic resource" - as it is determined in the international documents, in the experts' language - is, and will always remain the man, especially the man who knows how to presume and invest all his cognitive, creative and ethic potential.

In this prism, the European Union Council, with the recommendation of 24 September 1998, no. 98/561/Ce15, has recommended the Member States to support and when it is suitable, to create a transparent evaluation of the higher education quality; to encourage when it is appropriate, the higher education institutions, in cooperation with the respective departments of the member states to approve the right controlling measurements; to invite the competent authorities and higher education institutions to give special importance to the exchange of experience and the cooperation in the quality evaluation with the other member states and the international organizations, as well as the associations operating in the field of higher education; to promote the cooperation between the responsible authorities on the quality evaluation or assurance of in the higher education and to encourage their inclusion inside the net. The Council also asked the European Commission to undertake measures to encourage the cooperation among the responsible authorities on the evaluation and assurance quality in the higher education and the integration of the organizations and associations of higher education institutions with a European spirit which have the experience requested for the evaluation and assurance of the quality.

Immediately after that, in 19 June 1999, as it is already well known, in Bologna, the Education Ministers of the 29 States signed Bologna Declaration, which had as the main objective and as a priority creation of the European Higher Education Area, promotion of the European cooperation in quality assurance in order to create comparing criteria and methodologies.

In response to the stimulus of the Recommendation of the European Union Council and in Bologna Declaration, in 2000, is was established the European net for quality assurance of higher education, later called European Association for Quality Assurance in Higher Education (EAQA/ENQA). The aim of ENQA is to encourage the cooperation in the field of university quality assurance through various European agencies, national public authorities and Academic Institutions.

Actually, members of EQNA are all agencies for the higher education quality and accreditation of Austria, Belgium, Bulgaria, Cyprus, Czech Republic, Denmark, Estonia, Finland, France, Germany, Hungary, Ireland, Latvia, Lithuania, Holland, Norway, Poland, Romania, Russia, Serbia, Slovakia, Spain, Sweden, Switzerland, and United Kingdom.

Another fact to keep in mind is what happened immediately after the Bologna Declaration at the European Union,

${ }^{2}$ See the full text of Lisbon Convention in www.conventions.coe.int 
was the extraordinary meeting of the European Counsel in Lisbon in 2000, where important resolutions were taken about the fields related to the education, for, (then), the 15 Member States and now with its extension for all the Member States in EU. This meeting precursor to the one in Koln (04-05 June 1999), represents the moments when the politics and economics field have lighted the fire of the European collaboration, the convergence fire of the European pact for employment.

Based on this signed pact, over a general social and economical vision, it comes to Lisbon meeting, with the focus on the theme: toward an innovated Europe and knowledge, with the aim naturally to the launch of the formation policies. With this the European chairmen, of he States and their Government formulate a common strategic goal economicalpolitic of UE that is accomplish in 2010" to be more competitive the economics and more dynamic in the world ,able for establish growth, with more jobs and more quality, including a bigger social cohesion". meaning, in other words, to create a space, with more interaction: Educational and training policies in order to live and work in a society of knowledge, an active strategic policy of employment, modernizing protection social policies, and promoting of the social layer policies.

In the Council and European Commission the Education Sector is now known as a priority field of the Lisbon Strategy. The European Council of Lisbon held in dates: 23-24 March 2000 has as establish goal of Europe as the most competitive and dynamic force in the world, finding also useful to use innovative and new possibilities of the market and the particular moment of the Internet. This demonstrate the fact of general aims are made and taken decisions after studying and discussing a detailed program of jobbing and the initiatives that fulfill the challenges for sapience of the society and the globalization. In this line, European Institutions are creating quite a number of aims in Education and formation, to still achieve it in the year 2010. And all these processes are well linked with the Bologna Process that not only including the Member States but also other European states not yet in the Union. The main contents are like: Higher quality in Education and formation, Europe must be a wide world reference about quality and connection with its systems and its institutions, regarding those of Education and formation, the Education System and the Formation in Europe must be in accordance with each other to give a possibility to the citizens flow and take advance from their diversity, all of them who owns the qualifications, knowledge, and skills won all over Union European, will effectively guide the through all the UE for the aim of their carrier and their further studies. The Lisbon Pact also forms the main base for the revitalizing the Education and formation putting in principle some priorities: the development of the teaching along lifetime, taking a special overview the poor lays, the investment over the human resources, the growth of the Education level for the youth and offering a wide gamma of possible trainings, defining of the main specific skills, the increasing of the flow, including appropriate stimulus, the improving of job conditions regarding youth through alternative systems, including the old generation, encouraging the teaching/learning through a lifetime.

It must be stressed, that the sentence, verdicting, 253/200/KE of European Union Parliament and the Council that built "Socrates", a Community action program, in which could be realize a qualitative Education through common collaborating actions through the States, the student/professors flow inside the EU, the organized projections the creation of the European nets, the preparing studies and comparing analyzes.

In this context the European Council held in 5-6 May 2003 have shown some referring parameters for Education and Professional Formation to achieve it at 2010.we can underline here: the reduction of the abandonment $f$ the school inside a average percentage like $10 \%$, the completing of the pre-university cycle of $85 \%$ of the population, and the teaching/learning lifetime process.

It is valuable to mention the document: Education at glance: OECD, Indicators 2005 that could be taken as an indicated mirror of the general state of Education in European level containing a number of comparing indicators and learned over the advancing of the Education systems to the 30 States of that time.

While in Europe still continue to work over the creation of European Space of the High Education (HEAL),and harmonizing the architecture of the various national universities systems, at the other hand nowadays is still in progress the project for the Development of Scientific European Zone (ERA). The ministers of the participating State, now 47, meet every two years, to value the results achieved, and securing a continuous information in the process, creating the priorities and achievements for the next two years. After the first meeting in Bologna (1999)the ministers met in Prague in 2001,Berlin 2003,bergen 2005,London 2007,Louvein 2009 ,Wien-Budapest 2010 and this year in Bucharest 2012.The next meeting will take place in Armenia in 2015.

In the periods during minister conferences a main role was achieved by the so called group "Bologna Follow-Up Group", that gathers twice a year and is represented by all the signing States and the Union European Commission, European Council, Education International Pan-European Structure - ENQA, ESU, (representing students organ) EUA (European university association), EURASHE (representing the non-university structure), UNESCO-CEPES and Business Europe (the Industrials Confederation) that act as council members. At last, some seminars so called 
"Bologna" are held every year in different countries discussing issues linked to this subject and the process, to analyze the remaining obstacles and propose new ways of collaborations. Every biennial ministerial meeting ends with a declaration, in which ministers accept the achieved agreement and the new steps are taken for the creation of the European High Education Zone.

In the context just described comes out the Constitutional Pact that could not be ratified, that defined the article I-3 through the objections, scientific and technologic progress, respecting the cultural and language diversity, for the storage and the development of cultural heritage, the protection of the children rights.

Among the dispositions of the general implementation, article III-117-just introduced-predicted, that in specific defining and implementation of its policies European Union, keeps in advance, the requests linked to promoting of the employment and the social adequate protection, the battle against the social exclusion, and also a higher level of Education, Professional Formation, and the Protection of Human Health.

containing of the disposition is included in the Lisbon Treaty that entered in power on 1st December 2009.Title XII called: "Education, Proffesional Formation, Youth and Sport" and in particular in the article 165 TFBE and article 166 TFBE.

Article 165 textually states:

1. The Union contributes to the development of quality education by encouraging cooperation between Member States and, if necessary, by supporting and supplementing their action, while fully respecting the responsibility of the Member States for the content of teaching and the organization of education systems and their cultural and linguistic diversity.

The Union contributes to the promotion of European sporting issues, while taking account of the specific nature of sport, its structures based on voluntary activity and its social and educational function.

2. The Union action aims at:

$>$ developing the European dimension in education, particularly through the teaching and dissemination of the languages of the Member States,

$>$ encouraging mobility of students and teachers, by encouraging inter alia, the academic recognition of diplomas and periods of study,

$>$ promoting cooperation between educational establishments,

$>$ developing exchanges of information and experience on issues common to the education systems of the Member States,

$>$ encouraging the development of youth exchanges and of exchanges of social educational instructors, and encouraging the participation of young people in democratic life in Europe,

$>$ encouraging the development of distance education.

$>$ developing the European dimension in sport, by promoting fairness and openness in sporting competitions and cooperation between bodies responsible for sports, and by protecting the physical and moral integrity of sportsmen and sportswomen, especially the youngest sportsmen and sportswomen.

3. The Union and the Member States shall foster cooperation with third countries and the competent international organizations in the field of education and sport, in particular the Council of Europe.

4. In order to contribute to the achievement of the objectives referred to in this Article,:

$>$ the European Parliament and the Council, acting in accordance with the ordinary legislative procedure, after consulting the Economic and Social Committee and the Committee of the Regions, shall adopt incentive measures, excluding any harmonization of the laws and regulations of the Member States,

$>$ the Council, on a proposal from the Commission, shall adopt recommendations.

Article 166 TFBE textually states:

1. The Union shall implement a vocational training policy which shall support and supplement the action of the Member States, while fully respecting the responsibility of the Member States for the content and organization of vocational training.

2. Union action aims at:

> facilitating the adaptation to industrial changes, in particular through vocational training and retraining,

$>$ improving initial and continuing vocational training in order to facilitate vocational integration and reintegration into the labor market,

$>$ facilitating access to vocational training and encourage mobility of instructors and trainees and particularly young people,

$>$ stimulate cooperation on training between educational or training establishments and firms, 
$>$ develop exchanges of information and experience on issues common to the training systems of the Member States.

3. The Union and the Member States shall foster cooperation with third countries and the competent international organizations in the sphere of vocational training.

4. The European Parliament and the Council, acting in accordance with the ordinary legislative procedure and after consulting the Economic and Social Committee and the Committee of the Regions, shall adopt measures to contribute to the achievement of the objectives referred to in this Article, excluding any harmonization of the laws and regulations of the Member States, and the Council, on a proposal from the Commission, shall adopt recommendations.

\section{The European Space and Scientific Research}

The actions supported for the research and development in a Comminatory level are base on the KE treaty (ex 163-173 articles), throughout which as aimed an increased International concurrence. The action of those instruments as mentioned above is the "multi-annual framework program for research and technologic development", which has fixed periodical scientific and technologic goals that should be achieved demonstrating the general lines of the action itself in achieving the goals. In fact, these articles determine and define the sum of the financial contribute of the Community. Lately, some mechanism are approved and defined with financial character as the Framework Program (2002-2006), FP7 (continuing) in which the researching priorities are chosen from the process. Every Program has a budget of million Euros that serve for the structuring of the submitted project presented (from the universities, researching institutes, small and large entrepreneurs) and tend to involve multiple partners from different countries. In date 18 May 2000 The European Commission approved the Communiqué "toward a European Zone of research", quite a question of the EU future action in this field, it's aim being the help in improvement of general frame of the European research. The European Council in Lisbon has decided the goal for the Community to be more competitive in world until 2010 based on knowledge, while The European Council of Barcelona in March 2002 has identified its goals in the achievement of verge of $3 \%$ of PBB 's expenditure for researching, and development from the UE till the year 2010,prognosticating about two third of the sources invested in the research $\{2 \%$ of the PBB $\}$ should come from the private sectors. The Constitution Treaty \{article III.248], introduced the creation of a European researching space, in which the researchers, the scientific and technologic knowledge could rotate, move along, freely, in order to reinforce and strengthen the scientific and technologic foundations. Based on the Treaty, policies and EU actions should encourage the development of the concurrence, including the Industry, promoting all types of activities, and researching activities, considered basically necessary, from what the heads of the Treaty have been drawing and indicted. For this purpose to happen, EU encourages all the enterprises, researching centers and Universities in their scientific research, their activities of technologic development of high quality. The European Space of Research is characterized, on other hands, for its connection among the excellent centers net to the creation of virtual centers, and their interactive creative usage. Additional elements are given, added, through the mutual approval in connection with the needs, and the financial tools over the huge researching objects in Europe, and also the implementation coordinated more widely over the national researching programs and the invigorating of the relationship between different Organizations and European cooperation. Besides this, the European Space of Research aims to promote the investments in the private fields, which presuppose the effective guarding of the intellectual domain, interposition that encourages the creation of business and investment in capitals. In this context, the European Commission approved in 11 March 2005, a recommendation [2005/251/EC], linked to the European Card of the scientific researchers a Conduct [dealing] Code for the recruitment. The document started from the premises of the fact that the Employer or the financers must assure the legislative application [request] of the nation and assure the Member States and the researcher a mean to be taken, in a volunteer base, further initiations to advance and grow in the profession of the researcher in the EU and the creation of an open labor market. The recommendation aims at defining the ways and means in order to contribute to an open labor market, attractive, open and stable for all the scientific researchers where there are suitable conditions for the recruiting and employing of the scientific researchers of high quality profile, in a favorite environment. The Member States should provide the researchers stable systems for the development of their career in all its stages, although their contracting situation, and the career ways chosen and assure that the researchers should be treated like projectionists and be considered a component part of the Institutions where they are working. The implementation of Card guarantees that the nature of the relationship among the actors favors success in connection with the production, transferring, separation and distribution of the scientific and technological knowledge. At last, regarding the evaluation system, the Card 
recommends that the employers and/or the financiers, should approve, for all the researchers including also the experienced researchers, evaluation system that can provide an independent commission in order to estimate/evaluate periodically and transparently their professional services, considering their general creation in research and results, publications, for instance: patents, teaching management, research and lectures, surveillance, national or international cooperation, administrative tasks, activities to raise public awareness and mobility. These aspects should be considered for the career development. While the behavior code aims at recruiting, identification of simple and transparent procedures as well as to propose different selection criteria: "the merit should not be considered only with the number of publications but taking into account a larger number of criteria like: teaching, the skill to coordinate a scientific research group, work group, the skill to transmit and transfer the knowledge, leading activities, etc.

\section{The colons of the research in Bologna process:}

\subsection{The fundamental principles}

The Higher Education Law No. 9741, dated 21.5.2007 "On the higher education in the Republic of Albania", amended by the laws No. 9832, dated 12.11.2007, No. 10 307, dated 22.7.2010, has determined in compliance with the European standards the fundamental principles where it is based. The Law, in particular, aims to define the mission, the key goals of higher education and to regulate aspects of the creation, organization, management, administration, financing, quality assurance in the higher education institutions, in comply with the European standards. While the mission of higher education is: to create, to transmit, to protect and to develop knowledge through teaching, scientific research and service; to educate senior specialists and prepare young scientists; to provide opportunities to benefit from the higher education throughout life; to help the economic development at national and regional levels; to contribute in raising the standards of democracy and society civilization and in preparation of the young people for such a society (Article 2). Regarding the basic principles of this legislative, it is worthwhile to mention that they are described in some colons.

Firstly, the higher education institutions have autonomy and academic freedom. The autonomy of the higher education institutions is expressed in: a) their self governance to organize their internal structures and their activities, through statutes and regulations drafted according to this Law and other legal acts in power; b) the right to design and develop independent study programs and research projects; c) the right to set the criteria for accepting the students in the study programs; d) the right to raise funds and benefit material means in comply with the rules in power, as well as the right to carry out independent agreements with the government or other organizations for training, qualifications or research projects; e) the right to carry out agreements with institutions, business associations or other organizations, domestic or foreign, public or private; f) the right to administer the public funds and other incomes, which they possess as it is determined in the law. The academic freedom of higher education institutions is expressed in the freedom of teaching, freedom of scientific research, freedom of creation, according to the dispositions of this law. Higher education in Albania is developed in compliance with the rules and the principles of European Higher Education Zone (Article 3).

Higher education is public or private. It is offered by higher education institutions, established, operating and accredited according to this law. Higher education institutions are legal persons, public or private, their rights and their obligations are determined in the act of their establishment.

Bologna system in our country is now compulsory for all the institutions of higher education. This is clearly expressed in the higher education law, amended according to which, Article 83 states: "Public institutions of higher education, which were established before the entry into power of this law, should reorganize their internal structuring and the study programs according to this law, within one year of its entry into power" while the requirements for opening a new private institution of higher education, submitted before the entry into force of this law (2007), are reviewed in comply with the standards, the procedures and the terms defined in the laws and the acts that come out for its implementation (Article 84). The law on the reorganization of the private institutions of higher education has left a deadline for the reorganization within three years (Article 85). From this point of view, the system has turned to an obligation for all the institutions of higher education, thus disrespecting the principle based on the element 'optional' upon which Bologna Process is based. The other elements such as the ECTS system, the graduation system, students' and docents' mobility, the accreditation system, etc., are basically in full compliance with Bologna system, as in the other European countries.

\subsection{ECTS system and the graduation system}

One of the advantages of the higher education reform in Albania since 2003, it is the implementation of the European 
System of Credit Transfer System (ECTS). This system performs the evaluation and comparison of the achievements of studying as well as aims not only to transfer from one university to another within the country but also providing the academic recognition of studies abroad. In this way, ECTS is one of the basic instruments for achieving and implementing the Bologna reforms. In our country, at the beginning it was the University of Tirana which took the initiative for the construction of credit system, creating new curricula expressed in ECTS credits, since 2003, so that since the signing of Bologna agreement. This was the first significant step of recognizing the Albanian universities in the European network of higher education. Other universities in the country started implementing a system of credits during the academic year 2005-2006. With special instruction of MES end of the academic year 2005-2005 the list of grades accompanying the diploma, reflect not only national assessment marks but also the expression of cases and assessments of credits according to ECTS system as a whole. Also, in terms of the graduation system, according to the Guidelines of the Ministry of Education, higher education for the full duration, a semester is approximately 30 ECTS credits, while an academic year is approximately 60 ECTS credits. University Degree with full length contains 180 credits. The credits are considered earned in case when the student is assessed with passing mark in the relevant subject.

\subsection{Students' mobility}

Among the common policy objectives determined in the agenda of the European Council of Lisbon, it is worthwhile to mention: promoting of the mobility of the university students and its staff in the field of education and research (preventing the barriers for greater transparency in recognition of the qualifications and the periods of study and training); drafting of a common European format "curriculum vitae" that can be used voluntarily for movement.

\subsection{Scientific research}

Scientific research is thought that one of the weaknesses of higher education in Albania. In the wave of discussions for reforming of Higher Education and scientific research, it was carried out the melting of the Academy of Sciences. In practical terms, this means its transformation from a higher institution of research in an institution that no longer engages in scientific research, because the Academy became 'honorific'. From this time on, in Albania there are not any research institutes under the authority of the Academy, and there are not any public or semi-public research institutes. In this situation, the scientific research is exclusively concentrated in universities or centers within the universities. In this direction, currently there is not a single and truly politically independent institution, an institution developed on its bases, agile and versatile, reliable and evaluated by the Albanian society. In this direction, the scientific research can not be left only in the hands of the universities because this new tradition does not coincide with the traditions of the European countries that we confidently follow.

\section{Instead of the conclusions: the problems in Albania, some "fixable"}

The research question raised at the beginning of this study, thus: how close or far is the higher education in Albania to the European standards, can not have a satisfactory answer or to be more precise correct, complete in all the key elements that constitute the higher education, but only in principle and in some of its essential elements. In principle, the higher education in Albania is approaching European standards, as in the drafting of the laws and sub-legal acts as well as in the main delineation or main directions that the European countries already have. The legislation obligates the higher education institutions to be confirmed towards these laws including public institutions as well as non-public ones. In this direction, our country has made the system compulsory, unlike the spirit that pervades the Bologna Process.

In connection with the credit system and the graduation system, we can mention again the same result: these systems are basically in compliance with the European standards. If problems should be identified, these find expression in the number of educational programs, in their diversity and not always in comply with the labor market in Albania.

In connection with the scientific research, it can not be said that it is realized in full compliance with the European standards. Currently, there are the universities those which are leading the situation and seek to benefit from the state funds, regional funds or of European Union or of private investors to develop projects that are in their masterplan. Regarding this, if on one hand they can be considered strong poles for attraction of funds for the development of important projects, on the other hand, it can not be said that the scientific research can be left alone in this platform, so, therefore, the part of the legislation on the scientific research should be revised, as well as the whole structure on the scientific research institutions should be reorganized. 
On the other hand, one of the objectives of the participating countries participating in the Bologna process, their number has gone to 47 , is that by 2020 , around $20 \%$ of the students should have study experience in a foreign institution. Thus, it is required by then, the so called students' mobility should be realized. This objective will be achieved when the students provided with such general competencies, where the English language is priority, as the language of global communication, without underestimating the other languages. The reality of the actual study programs in most of our universities is still far from accomplishment of this objective. It is necessary to harmonize the programs within the country, later at regional and European level, in order to achieve the whole Albanian objective, that of integration and involvement in the global market. The study programs should be reviewed through all the cycles, to reduce the number of those in Bachelor level, to increase the number of professional Master programs and the research elements should extend in all the cycles, starting with what is applied and continuing further more with deep researches, especially in Masters of Science and doctorates (PhDs). Today, it is required that the students should be prepared with general and specific competencies for their profession, based on research and innovation, because that is necessary for the economic and social development of the country. In the conclusion of this paper, it is worthwhile to mention that the problems our country faces are not dictated by the Bologna Process in itself, or by the system itself. They are dictated and amplified by the Albanian reality, by the nature and the behavior of the Albanian society, and above all by the main actors who "build" day by day the Bologna system in our country. Despite the lacunae or the problems that associate this process, it should be stressed that these are problems that can be willfully and easily overcome and could lead to further improvement of the higher education system in Albania.

\section{References}

Beerkens, E. (2008). The Emergence and Institutionalization of the European Higher Education and Research Area. European Journal of Education, 43(4), 407-425.

Bomberg, E., \& Peterson, J. (2000). Policy Transfer and Europeanization: Passing the Heineken test. Queen's Papers on Europeanization (2).

Börzel, T. A. (2003). Shaping and Taking EU Policies: Member State Responses to Europeanization. Queen's Papers on Europeanization (2).

Commission, E. (2010). State of Play of the Bologna process in the Tempus Countries (2009 - 2010), Luxembourg: European Commission.

Corbett, A. (2005). Universities and the Europe of knowledge: Ideas, institutions and policy entrepreneurship in European Union Higher Education Policy, 1955-2005. Basingstoke: Palgrave MacMillan.

Cowles, M. G., Caporaso, J., \& Risse, T. (Eds.). (2001). Transforming Europe: Europeanization and domestic change. Ithaca, NY: Cornell University Press.

EURYDICE. Focus on the structure of higher education in Europe 2006/07. National trends in the Bologna Process. EURYDICE, European Unit, Brussels, March 2007.

Falkner, G. (2003). Comparing Europeanization Effects: From Metaphor to Operationalization. European Integration online Papers, $7(13)$.

Gjuraj T., Ide të sistemuara për universitetin privat \& publik, UETPRESS, 2012

Konomi, N. (1992). Albania. In B. R. Clark \& G. Neave (Eds.), The Encyclopedia of Higher Education (Vol. 1: National Systems of Higher Education, pp. 9-12). Oxford: Pergamon Press.

Kozma, T. (2008). Political Transformations and Higher Education Reforms. European Education, 40(2), 29-45.

Keeling, R. (2006). The Bologna Process and the Lisbon Research Agenda: the European Commission's expanding role in higher education discourse. European Journal of Education, 41(2), 203-223.

Kehm, B. M., Huisman, J., \& Stensaker, B. (2009). The European higher education area: perspectives on a moving target. Rotterdam: Sense Publishers.

Malizia G., e sollecitazioni della riforma universitaria alla riconfigurazione delle Facoltà e degli Istituti teologici. Quali apporti significativi e utili?, Itinerarium 13 [2005] 30, 215.

Mehmeti, E. (2006). The Experience of Albanian Universities in Implementing Students and Staff Mobility Master, University of Tampere, Tampere.

Musai B., et al. "National Report: Albania." (2006) in: P. Zgaga (ed.), The prospects of teacher education in South East Europe. South East European Educational Cooperation Network (SEE-ECN), Center for Educational Policy Studies, University of Ljubljana (Slovenia).

Nelaj, D. (2009). Policy and practice in the Albanian HE governance: a research based on three case studies.

OECD. (2003a). Reviews of National Policies for Education South Eastern Europe. Vol. 1: Albania, Bosnia and Herzegovina, Bulgaria, Croatia, Kosovo Paris: OECD.

Scurati C. e Bocca G., Università al futuro: finestre sul mondo, Vita e Pensiero 1 [1999]72-100.

Spiro, M. (2003). Academic Values and Academic Work in the Era of Globalization: The Case of Albanian Universities. Higher Education 
in Europe, 28(3), 311-313.

Towards the European Higher education area. Communiqué of the meeting of the European Ministers in charge of higher education (Prague Communiqué), Praga 2001;

Realising the European higher education area. Communiqué of the Conference of Ministers responsible for Higher Education (Berlin Communiqué), Berlin 2003

World Data Education, (2010/2011) 7th Edition Report. 